\title{
PENERAPAN PENDEKATAN BELAJAR CATUR ASRAMA MELALUI TAKSONOMI TRI KAYA PARISUDHA DALAM PKN (Studi Quasi Experiment Terhadap Peningkatan Kompetensi Kewarganegaraan Siswa SMA Negeri Di Kota Singaraja)
}

\author{
I Wayan Budiarta
}

\author{
Program Studi PPKn \\ Jurusan Hukum dan Kewarganegaraan \\ Universitas Pendidikan Ganesha Singaraja \\ Email : budiartaiwayan@ymail.com
}

\begin{abstract}
Abstrak
Pada dasarnya penelitian ini mengambil keyakinan masyarakat Bali bahwa agama, kebudayaan, ilmu pengetahuan dan pendidikan adalah satu hal yang kontinum, seperti Albert Einstein yang menyatakan "science without religion is lame, religion without science is blind. Secara yuridis-normatif keyakinan ini telah tercermin dalam sistem pendidikan nasional kita yang tersurat dalam UUD 1945 dan Undang-Undang Sistem Pendidikan Nasional. Tetapi sayangnya karena dominasi dan hegemoni praktek pendidikan nasional yang cenderung mengabaikan nilai-nilai agama dan budaya spiritual, sehingga prinsip pendidikan yang humanis, holistik, religius belum tercapai dengan baik. Jika pendidikan tidak ingin mencabut generasi mudanya dari akar budayanya, maka praktek PKn perlu ditransformasikan ke arah praktek pendidikan yang humanis-holistik dan religius dengan mengintegrasikan kearifan lokal masyarakat yang bersumber dari nilai-nilai ajaran agama (local genius). Penelitian ini bertujuan untuk mengetahui pengaruh yang signifikan pada peningkaan kompetensi kewarganegaraan siswa dengan menggunakan "Pendekatan Belajar Catur Asrama melalui taxonomi Tri Kaya Parisudha" dibandingkan dengan pendekatan belajar PKn konvesional. Penelitian ini mengambil lokasi di SMA Negeri di kota Singaraja dengan metode penelitian Quasi Experiment. Sampel penelitiannya adalah 8 kelas yakni berjumlah 233 orang siswa dari empat SMA Negeri yang ada di kota Singaraja. Secara umum, hasil penelitian menunjukkan bahwa ada pengaruh yang signifikan pada peningkaan kompetensi kewarganegaraan dalam hal pengetahuan kewarganegaraan (civic knowledge), sikap kewarganegaraan (civic disposition), dan keterampilan kewarganegaraan (civic skills) siswa SMA Negeri di kota Singaraja dengan menggunakan pendekatan belajar Catur Asrama melalui taxonomi Tri Kaya Parisudha dibandingkan dengan penggunaan pendekatan belajar PKn konvensional.
\end{abstract}

Keywords: $\quad$ Catur Asrama, Tri Kaya Parisudha, Civic Education, Civic Competence.

\begin{abstract}
Basically this research takes the belief of the Balinese people that religion, culture, science and education are a continuum, such as Albert Einstein who stated "science without religion is lame, religion without science is blind. Juridically, this belief has been reflected in our national education system which is written in the 1945 Constitution and the National Education System Act. But unfortunately because of the dominance and hegemony of national education practices that tend to ignore religious values and
\end{abstract}


spiritual culture, so the principle of education that is humanist, holistic, religious has not been achieved well. If education does not want to uproot the younger generation from its cultural roots, then the practice of PKn needs to be transformed towards the direction of humanist-holistic and religious education practices by integrating the local wisdom of the community from the source of religious teachings (local genius). This study aims to determine the significant effect of increasing the citizenship competency of students by using the "Dormitory Chess Learning Approach through Tri Kaya Parisudha taxonomy" compared to the conventional Civics Education learning approach. This study took place in the State High School in the city of Singaraja with the Quasi Experiment research method. The research sample was 8 classes, totaling 233 students from four public high schools in the city of Singaraja. In general, the results of the study show that there is a significant influence on increasing citizenship competencies in terms of civic knowledge, civic disposition, and civic skills of high school students in Singaraja using the Dormitory Chess learning approach. through Tri Kaya Parisudha's taxonomy compared to the use of conventional PKn learning approaches.

Keywords: Dormitory Chess, Tri Kaya Parisudha, Civic Education, Civic Competence.

\section{Pendahuluan}

Hampir semua kalangan sepakat dan telah menjadi pengetahuan umum khususnya dikalangan akademisi PKn, bahwa "tujuan dari PKn (civic education dan citizenship education) adalah untuk membentuk warga negara yang baik dan cerdas (to be smart and good citizenship)" (Wahab dan Sapriya, 2011: 10). Kemudian Somantri (2001: 279) menyatakan bahwa tujuan umum pelajaran PKn ialah mendidik warga negara agar menjadi warga negara yang baik, yang dapat dilukiskan dengan warga negara yang patriotik, toleran, setia terhadap bangsa dan negara, beragama, demokratis, dan Pancasila sejati. Menurut Maftuh dan Sapriya (2005: 30), bahwa tujuan negara mengembangkan PKn, agar setiap warga negara menjadi warga negara yang baik (to be good citizens), yakni warga negara yang memiliki kecerdasan (civic intelligence) baik intelektual, emosional, sosial, maupun spiritual; memiliki rasa bangga dan tanggung jawab (civic responsibility); dan mampu berpartisipasi dalam kehidupan masyarakat.
Hal di atas menunjukkan bahwa PKn merupakan conditio zine qua non dalam pendidikan nasional Indonesia. Keniscayaan PKn sebagai usaha untuk pembentukan warga negara yang baik dan cerdas ini dibuktikan di dalam dokumen formal kenegaraan dan kurikulum pendidikan. Di samping itu, paradigma PKn yang telah dikonsepsikan oleh para akademisi PKn, yakni hakekat, visi, misi serta tujuan PKn dapat membuktikan betapa pentingnya $\mathrm{PKn}$ bagi kehidupan masyarakat, bangsa, dan negara Indonesia (Winataputra, 2001).

Namun sayang, tujuan mulia PKn ini tidak diiringi oleh rialitas pembelajaran dan hasil belajar PKn yang utuh dan powerful. Pembelajaran PKn yang umum dilakukan di sekolah kurang mengitergrasikan seluruh potensi dan dimensi kecerdasan manusia (intelektual, emosional, personal, sosial, moral, dan spiritual). Sedangkan secara subsatnsial, negara Indonesia membutuhkan warga negaranya memiliki kompetensi yang utuh dan terintegrasi. Sukadi (2010: 4) menjelaskan bahwa kecendrungan 
pembelajaran PKn di Bali menunjukan pembelajaran yang di dominasi oleh hegemoni praktik pendidikan nasional yang cenderung mengabaikan nilai-nilai holistik-humanis-religius, karena dikuasai oleh ideologi kapitalis yang cenderung menekankan pada carapandang rasionalisme-empirsme atau rasionalitis-materialistis, sehingga roh pendidikan yang berlandaskan nilainilai moral dan spiritual yang suci kian waktu cenderung menampakkan gejala sekulerisasi. Kaelan (2003: 10) menyebutkan “...di sini dunia pendidikan nasional kita seperti dunia negara sekuler yang cenderung memisahkan antara kepentingan ideologi agama dan ideologi ilmu pengetahuan".

Sejalan dengan pemikiran di atas, seharusnya praktik pembelajaran PKn di sekolah juga perlu dilakukan melalui pemikiran yang lebih holistik-humanisreligius yang terintegrasi. Dilihat dari visinya, pembelajaran PKn ke depan tidaklah cukup membangun warganegara yang demokratis dan rasional saja, tetapi juga perlu mengembangkan visi beriman, bermutu, dan berbudaya. Begitu pula dengan misinya, pembelajaran $\mathrm{PKn}$ tidaklah cukup mewujudkan misi sosiopaedagogis saja, melainkan juga secara terintegrasi perlu mewujudkan misi sosio-akademis, sosio-kultural, dan sosio-religius (Sukadi, 2010).

\section{Kajian Teoritis \\ Paradigma \\ Pendidikan \\ Kewarganegaraan}

Penelitian ini tidak terlepas dari paradigma PKn yang telah dikonsepsikan dan dikembangkan oleh para akademisi dan praktisi PKn kita. Winataputra (2001) menjelaskan bahwa hakikat PKn dalam paradigma barunya adalah sebagai program pendidikan,
PKn sebagai bidang kajian ilmiah bersifat multidimensi; dan PKn sebagai program sosio-kultural yakni sebagai pendidikan partisipasi aktif warga negara dalam konteks kehidupan bermasyarakat, berbangsa dan bernegara.

Winataputra (2001: 294) juga menjelaskan bahwa PKn mengemban visi sebagai berikut. Pertama, PKn mengemban visi sebagai program pendidikan tentang, melalui, dan untuk kewarganegaraan (education about, through, and for citizenship). Kedua, PKn juga diharapkan dapat menjadi wahana pendidikan demokrasi yang mampu menciptakan dan mewujudkan belajar demokrasi, dalam demokrasi, dan untuk demokrasi (learning democrasy, in democrasy, and for democrasy) bagi setiap insan warga masyarakat dan warga negara. Ketga, visi PKn seperti ini diarahkan dalam usaha mewujudkan visinya sebagai pendidikan untuk membangun karakter bangsa.

Hal ini memberikan penjelasan kepada kita, bahwa pentingnya PKn di Indonesia yakni untuk mewujudkan warga negaranya agar mampu "berpikir glogal, bertindak lokal, dan komit terhadap bangsa dan negaranya (think globally, act locally, and commit nationally)" (Somantri, 2001; Wahab, 2001; Winataputra, 2001; Sukadi 2010). Berdasarkan uraian hakikat PKn di atas, Winataputra (2001: 288) menjelaskan, bahwa PKn memiliki misi sosiopaedagogis, sosio-akademis, dan sosiokultural". Dengan misi sosiopaedagogis PKn berkewajiban memberdayakan peserta didik melalui proses-proses pendidikan, pengajaran, dan pelatihan untuk memiliki tujuh kecakapan kewarganegaraan yang meliputi: civic knowlidge, civic disposition, civic skills, civic confidece, civic commitment, civic competence, dan 
civic culture yang terintegrasi dalam kemampuan berpikir, bersikap, dan bertindak sebagai insan warga negara
Indonesia yang berkarakter dan demokratis (Sukadi, 2010).

\section{Gambar Paradigma Pendidikan Kewarganegaraan di Indonesia}
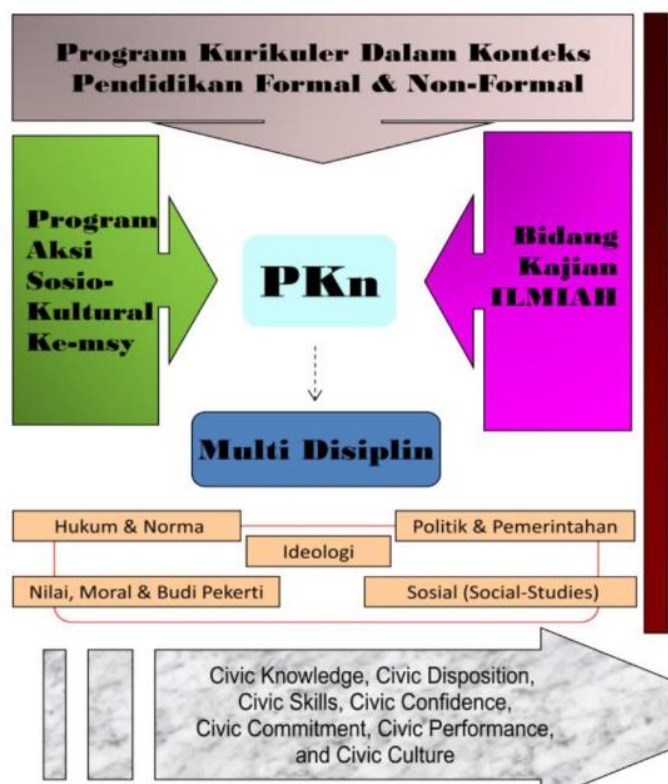
Civic Skills, Civic Confidence, Civic Commitment, Civic'Performance, and Civic Culture

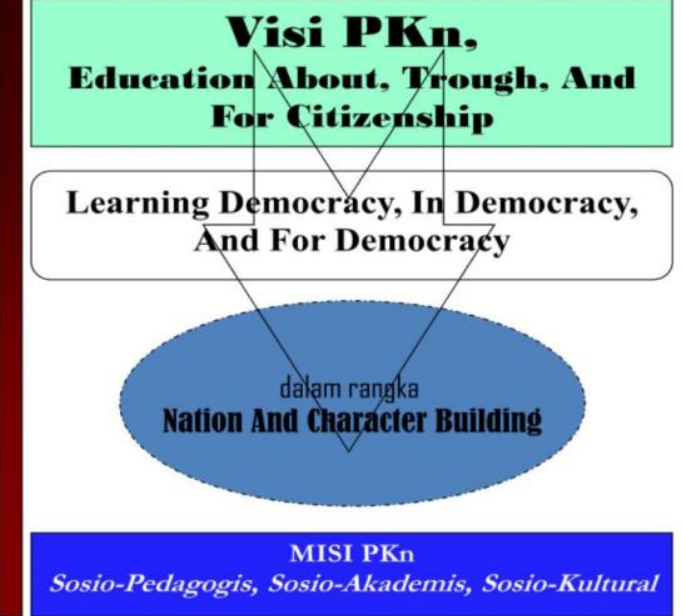

TUJUAN PKn

Warga Negara Yang IBaik

To Be Smart AGood Citizemship

Sumber: diadopsi dari Winataputr (2002) Jati Diri Pendidikan Kewarganegaraan sebagai Wahana Sistemik Pendidikan Demokrasi: Suatu Kajian Konseptual dalam Konteks Pendidikan IPS. Disertasi. Bandung: UPI.

Dengan misi sosio-akademis PKn haruslah dapat berfungsi bagi peserta didik untuk bersama-sama secara akademis mengembangkan kehidupan kewarganegaraan dan berdemokrasi yang lebih baik melalui berbagai kegiatan berpikir dan inkuiri reflektif terhadap berbagai masalah kewaganegaraan dalam kehidupan bermasyarakat, berbangsa, dan bernegara (Sukadi, 2010). Selanjutnya, PKn haruslah dapat menjadi sarana rekonstruksi sosial bagi pendidik dan peserta didik dalam menerapkan prinsip berpikir dan penelitian ilmiah terutama menciptakan kehidupan kewarganegaraan yang demokratis yang lebih baik. Dengan misi sosio-kultural,
PKn haruslah dapat berfungsi bagi pendidik dan peserta didik untuk secara bersama-sama mengabdi kepada masyarakat, bangsa, dan negara. Di sini PKn harus dapat menjadi wahana partisipasi sosial politik kewarganegaraan bagi pendidik dan peserta didik untuk kepentingan bersama dalam kehidupan demokratis menuju tujuan nasional negara Indonesia yang lebih baik berdasarkan pada Pancasila dan UUD 1945 (Sukadi, 2010).

\section{Pembelajaran PKn Berbasis Kearifan Lokal}

Dalam disiplin antropologi kearifan lokal dikenal dengan istilah local genius, yakni istilah yang pertama 
kali diperkenalkan oleh Quaritch Wales yang dijelaskan sebagai "the sum of the cultural characteristics which the vast majority of people have in common as result of their experiences in early life", yakni keseluruhan karakteristik budaya masyarakat dalam gagasan-gagasan, nilai-nilai-nilai, pandangan-pandangan setempat yang bersifat bijaksana, penuh kearifan, bernilai baik, yang tertanam dan diikuti oleh anggota masyarakatnya (Ayatrohaedi, 1986; Sartini, 2004). Kemudian Mundardjito (dalam Ayatrohaedi 1986: 40) mengidentifikasikan ciri-ciri local genius itu pada dasarnya yakni: mampu bertahan terhadap budaya luar, memikliki kemampuan mengakomodasi unsur-unsur budaya luar, mempunyai kemampuan mengintegrasikan unsurunsur budaya luar ke dalam budaya asli, memiliki kemampuan mengendalikan, dan mampu memberikan arah pada perkembangan budaya.

Berdasarkan beberapa definisi yang disampaikan oleh para ahi di atas penulis dapat menginterpretasikan bahwa kearifan budaya lokal ini tidaklah dapat dipisahkan dalam konteks kehidupan masyarakatnya termasuk juga dalam pendidikannya. Seperti apa yang dijelaskan oleh Giroux (1981: 26) dan Pai (1990: 3) bahwa ada hubungan yang erat antara budaya masyarakat dengan pendidikan. Pendidikan dipengaruhi oleh society's prevailing worldview and values", pendidikan sebagai bagian dari kehidupan manusia tidak bisa dilepaskan dari konteks dan proses sosial budaya masyarakat yang melingkupinya, termasuk nilai-nilai yang terkandung di dalamnya. Hal seperti ini sesuai dengan pandangan Ki Hajar Dewantara dan Djayakarta bahwa pendidikan adalah proses membudayakan manusia dan masyarakat (Redja Mudyahardjo, 2001). Sedangkan Murdiono (2010) menyatakan, "agar tujuan PKn dapat tercapai dengan baik maka perlu dikembangkan strategi pembelajaran yang dapat mengembangkan kompetensi kewarganegaraan; salah satu strategi yang dapat dipilih yakni dengan mengembangkan strategi pembelajaran kewarganegaraan berbasis kearifan lokal".

\section{Pendekatan Belajar Catur Asrama Melalui Taxonomi Tri Kaya Parisudha} Berdasarkan filsafat Hindu, landasan filosofis "pendekatan belajar Catur Asrama" adalah pandangan masyarakat tentang hakekat belajar sebagai yadnya. Konsep belajar menurut perspektif Hindu yakni "belajar adalah yadnya", bahwa belajar itu adalah proses membangun pengetahuan suci oleh subjek belajar sendiri berdasarkan pengalaman yang terus dikembangkan untuk dapat menyesuaikan diri dengan lingkungan alam, sosial budaya dan spiritual masyarakatnya sehingga menghasilkan kompetensi yang utuh dan terintegrasi yang dapat dijadikan sebagai suatu persembahan yang tulus dan suci kepada Tuhan (Sukadi, 2010: 21).

Belajar menurut pandangan masyarakat Hindu dapat disejajarkan dengan pandangan kontruktivisme, tetapi tidaklah hanya berdasarkan konstruktivisme personal atau sosial saja seperti halnya konstruktivisme Piaget, Jhon Dewey dan Vigotsky, melainkan menggunakan basis konstruktivisme budaya spiritual (Suparno, 1997; Sukadi, 2010: 21). Belajar membangun pengetahuan suci sebagai yadnya seperti ini dapat dianalogikan seperti Arjuna dalam cerita pewayangan "MAHABARATHA" yang mengembangkan pengetahuan suci dengan melaksanakan kewajiban dan melakukan perang suci. 


\section{Gambar Hubungan Proses Belajar antara Badan Jasmani, Indra, Pikiran, Budhi, dan Atman dalam Membangun Pengetahuan Suci Manusia}

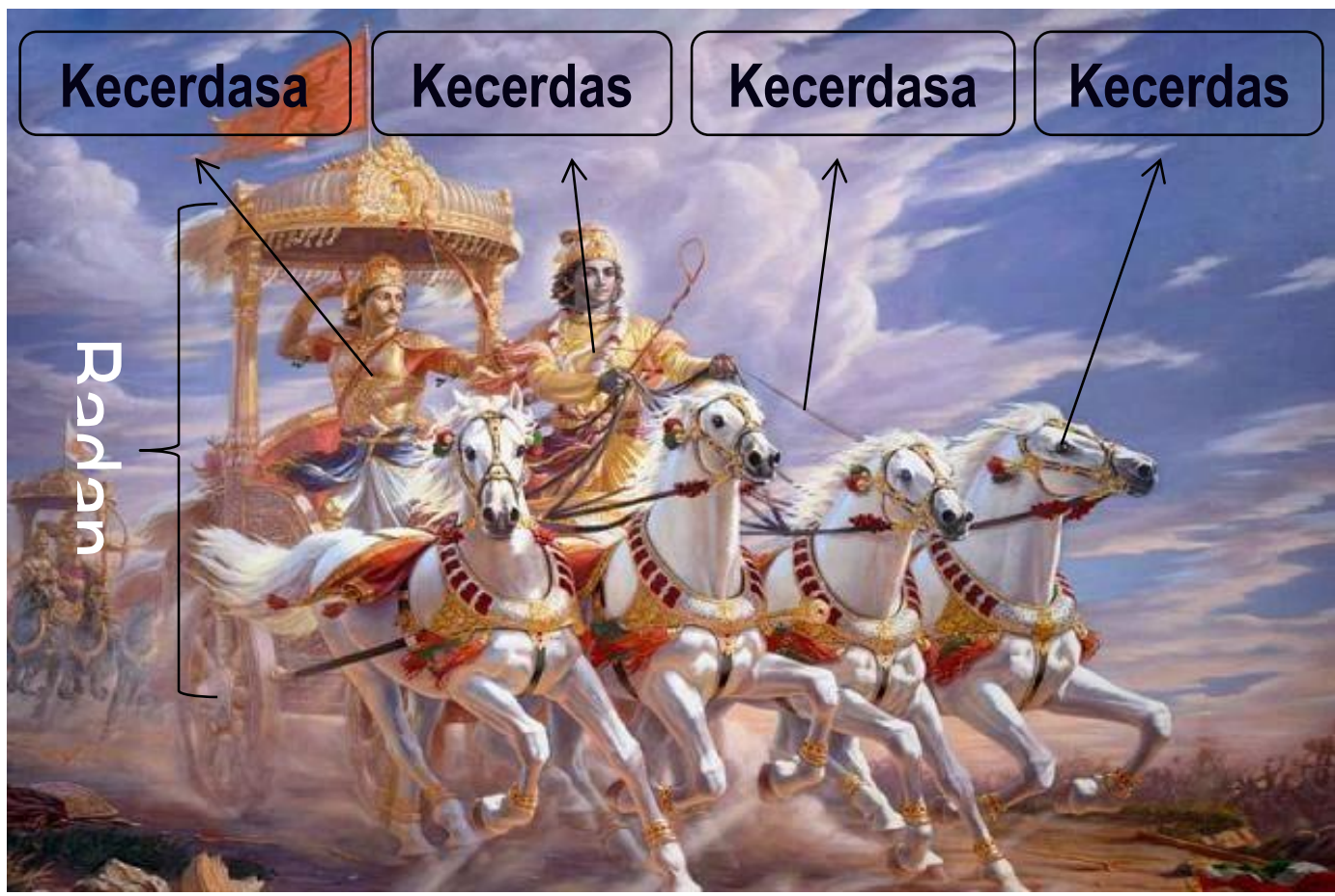

Sumber: diambil dari Bagavawad-Gita (Sri Srimad. A.C Bhaktivedanta Swami Prabhupada, 2005) dan Sukadi (2010: 17)

Dalam kehidupan masyarakat Hindu di Bali, pemikiran mengenai pendidikan dan belajar tidak dapat dilepaskan dari konsep-konsep yadnya. Pertama, setiap orang Bali yakin bahwa dalam hidup mempunyai utang (Rna), yaitu hutang kepada Tuhan (Dewa Rna), hutang kepada orang tua dan leluhur (Pitra Rna), hutang kepada guru (Rsi Rna), hutang kepada negara (Negara Rna), hutang kepada alam lingkungan (Butha Rna). Karena manusia berhutang, maka wajib baginya untuk membayar hutang tersebut dengan berdharma (melaksanakan kewajiban suci), berkarma (berbuat kebajikan), dan beryadnya (beribadah dan bersedekah).

Ketiga konsep ini (berdharma, berkarma, dan beryadnya) sesungguhnya identik dengan konsep belajar. Dalam belajar manusia haruslah belajar mengaktualisasikan dirinya. Diyakini bahwa manusia sesunguhnya telah membawa karmanya sendirisendiri yang berupa konsekuensi dari kehidupan terdahulunya. Proses manusia belajar mengaktualisasikan potensi dirinya mengalami empat siklus belajar (Catur Asrama), yaitu brahmacari belajar mandiri, grehasta belajar berkelompok secara keoporatif membentuk kesatuan unit-unit keluarga dan kelompok masyarakat, wanaprasta belajar secara kritis merefleksikan diri, introspeksi melalui perenungan yang mendalam (tapa, brata, yoga, semadi), dan bhiksuka belajar mengimplemntasikan ajaran Tuhan dan untuk kepentingan orang banyak (Sukadi, 2010: 17). Proses belajar seperti ini dilakukan dengan mengoptimalkan tiga potensi belajar yang disebut Tri 
Kaya Parisudha (kemampuan berpikir manacika; kemampuan berkata-kata dan berkomunikasi yang baik wacika; dan kemampuan bertindak dan berbuat dengan baik kayika).

Pendekatan belajar Catur Asrama melalui taksonomi Tri Kaya Parisuda" dalam PKn untuk tujuan meningkatkan kompetensi kewarganegaraan siswa disusun ke dalam sintak pembelajaran PKn sebagai berikut :

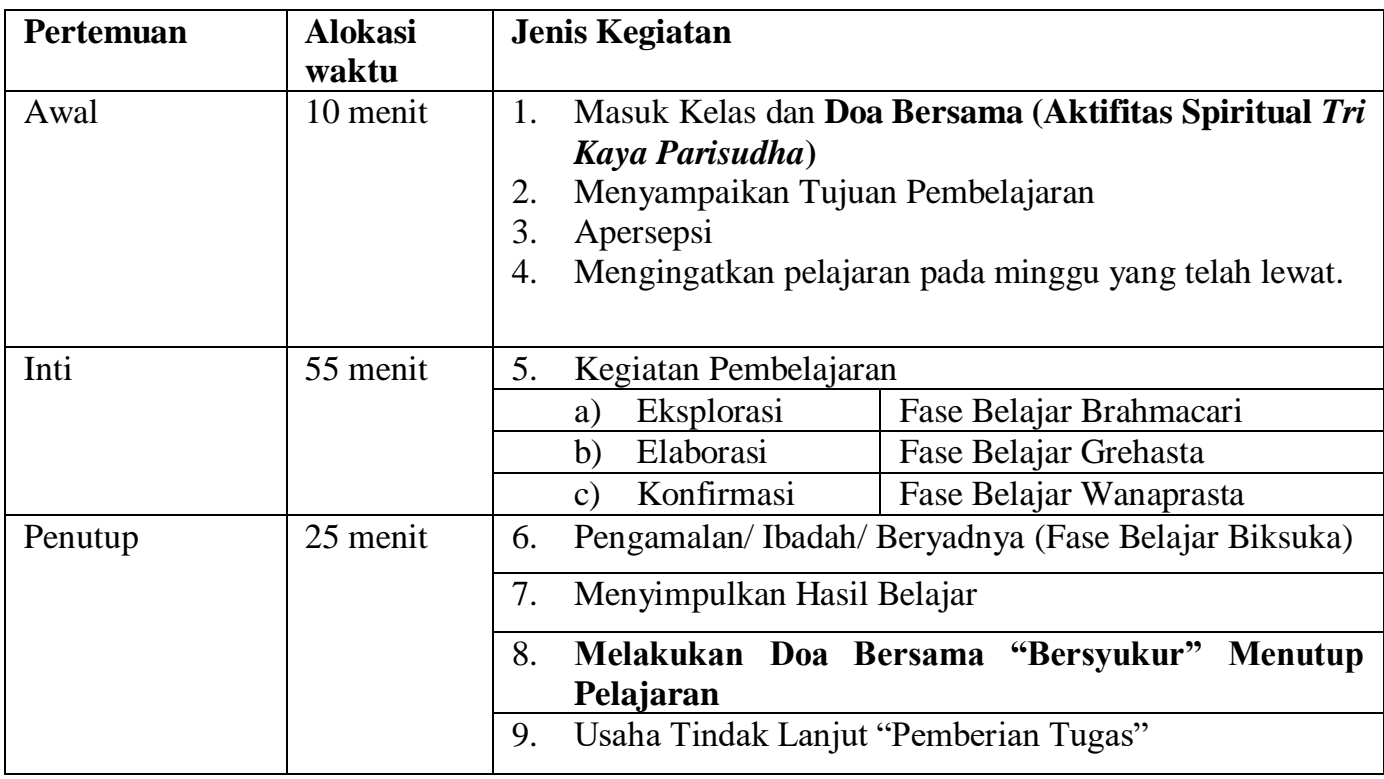

\section{Metode Penelitian}

Penelitian ini menggunakan pendekatan penelitian kuantitatif dengan metode quasi eksperimen "Nonequevalent Control Goup Desain (Sugiyono, 2010). Desain yang digunakan melibatkan dua kelompok kelas, yakni: pertama sebagai kelas eksperimen mendapatkan perlakuan dengan penerapan pendekatan belajar Catur Asrama melalui taxonomi Tri Kaya Parisudha, dan kelas yang kedua sebagai kelas kontrol dengan menggunakan metode belajar PKn konvensional. Penelitian ini mengambil lokasi di SMA Negeri di kota SingarajaBali pada kelas $\mathrm{X}$ Tahun Ajaran 2013/2014. Data utama penelitian ini adalah hasil belajar PKn yaitu kompetensi kewaganegaraan siswa yang dilakukan melalui pemeberian test objektif pilihan ganda untuk mengukur civic knowledge, inventori nilai untuk mengukur civic disposition, dan format peneilaian diri untuk mengukur civic skills. Tehnik analisis data dalam penelitian ini menggunakan analisis kuantitatif dengan analisis statistik deskriptif untuk mendeskripsikan skor rata-rata dan simpangan baku hasil belajar kewarganegaraan dan Multivariate Analysis of Varians (MANOVA) untuk menguji hipotesis.

\section{Hasil Penelitian Dan Pembahasan}

\section{Peningkatan Kompetensi}

Kewarganegaraan Siswa dengan Pendekatan Belajar Catur Asrama Melalui Taxonomi Tri Kaya Parisudha

Koefisien Adjusted $R$ Squared hasil penelitian untuk masing-masing variabel terikat dapat menunjukkan signifikansi pembelajaran terhadap sekor hasil belajar kewarganegaraan siswa SMA Negeri di kota Singaraja antara kelas eksperimen dengan kelas 
kontrol. Perbedaan perlakuan pembelajaran ternyata menyumbang secara signifikan sebesar $\mathbf{3 4 , 6} \%$ terhadap sekor tingkap pengetahuan kewarganegaraan (civic knowledge), sebesar 7,9 \% terhadap sekor orientasi nilai kewarganegaraan (civic disposition), dan sebesar 43,1 \% terhadap sekor keterampilan kewarganegaraan (civic skill) dengan taraf signifikasi 5\%. Hal ini menjelaskan bahwa penerapan pendekatan belajar Catur Asrama melalui taxonomi Tri Kaya Parisudha dalam PKn signifikan mempengaruhi peningkatan kompetensi kewarganegaraan siswa, baik dalam hal pengetahuan, sikap, dan keterampilan kewarganegaraan siswa SMA Negeri di kota Singaraja dibandingkan dengan penerapan pendekatan belajar PKn konvensional.

Hal ini sesuai dengan hasil penelitian terdahulu yang dilakukan oleh Sukadi (2010); bahwa secara deskriptif model pembelajaran PKn sebagai yadnya memberikan kategori hasil belajar PKn siswa yang cukup pada aspek pengetahuan kewarganegaraan, kategori tinggi pada aspek orientasi nilai kewarganegaraan, dan kategori cukup pada aspek tingkat laku kewarganegaraan. Penerapan model pembelajaran PKn sebagai yadnya berpengaruh secara signifikan terhadap hasil belajar PKn siswa pada aspek pengetahuan, orientasi nilai, dan tingkah laku kewarganegaraan baik secara bersama-sama maupun secara parsial.

Hal ini juga didukung oleh hasil penelitian yang dilakukan oleh Subagia dan Wiratma (2005) yang menyatakan bahwa ada hubungan yang erat antara pendidikan dengan budaya spiritual yang bersumber dari nilai-nilai ajaran agama yang diyakini oleh masyarakat Bali di dalam usaha mewujudkan tujuan pendidikannya. Dan secara teoritis hasil penelitian ini diperkuat oleh teori yang di kosepsikan oleh Giroux (1981: 26) dan Pai (1990: 3) yang menyatakan bahwa ada hubungan yang erat antara pendidikan dengan budaya masyarakatnya yang terwujud dalam kearifan lokalnya, dan pendidikan juga dipengaruhi oleh society's prevailing worldview and values", dalam artian pendidikan tidak bisa dilepaskan dari konteks dan proses sosial budaya masyarakat yang melingkupinya, termasuk nilai-nilai yang terkandung di dalamnya. Subagia dan Wiratma (2008) juga menjelaskan bahwa proses pembelajaran berdasarkan kearifan lokal yang bersumber dari ajaran agama dapat mengoptimalkan tiga potensi belajar manusia (Tri Kaya Parisudha) yakni dalam kemampuan berpikir yang jernih manacika, kemapuan berkata-kata dan berkomunikasi yang baik dan benar wacika; dan kemampuan bertindak dengan baik dan benar kayika.

Peningkatan yang signifikan pada kompetensi kewarganegaraan dalam hal pengetahuan, sikap, dan keterampilan kewarganegraan siswa ini dihasilkan dari penerapan pendekatan pembelajaran PKn melalui 3 tahap pembelajaran dengan 10 langkah pembelajaran yakni dengan: (1) Guru masuk kelas mengucapkan salam pembuka, kemudian dilakukan doa bersama sebagai aktifitas spiritual "Tri Kaya Parisuda"; (2) Guru menyampaikan tujuan pembelajaran; (3) Guru memberikan apersepsi; (4) Guru mengingatkan pelajaran pada mingguminggu yang telah lewat; (5) Fase eksplorasi melalui fase belajar Brahmacari; (6) Fase Elaborasi melalui fase belajar Grehastha; (7) Fase konfirmasi melalui fase belajar Wanaprastha; (8) Fase belajar Biksuka dan Beryadnya; (9) Klarifikasi dan 
menyimpulkan hasil belajar; (10) Melakukan doa bersama dan bersyukur. Pembelajaran Catur Asrama melalui taxonomi Tri Kaya Parisudha pada tahap awal pembelajaran yang dilakukan adalah sebagai berikut: guru masuk kelas kemudian dilakukan doa bersama sebagai aktifitas spiritual "Tri Kaya Parisuda" yaitu pengendalian terhadap pikiran (manahcika), pengendalian perkataan (wacika), dan pengendalian tindakan (kayika) untuk menuju kesiapan siswa dan guru dalam mengikuti pembelajaran PKn. Setelah itu, guru menyampaikan tujuan pembelajaran dengan penyampaian masalah untuk dapat dipecahkan oleh siswa. Selanjutnya guru memberikan apersepsi berupa materi kaitan untuk membangkitkan minat belajar PKn siswa. Proses selanjutnya adalah guru mengingatkan pelajaran pada mingguminggu yang telah lewat untuk melatih komplesitas informasi awal yang dimiliki siswa atau untuk memaksimalkan pengetahuan awal siswa (Sukadi, 2010).

Berdasarkan prosedur awal pembelajaran Catur Asrama ini terutama dalam hal upaya guru membangkitkan aktifitas spiritual siswa, terbukti signifikan dalam meningkatkan hasil belajar siswa. Melakukan doa bersama secara hikmad dan khusuk sebagai pembuka pembelajaran PKn merupakan langkah penting dalam pembelajaran Catur Asrama ini. Tujuannya adalah seperti apa yang dikonsepsikan dalam konstruktivisme De Vries dan Zan bahwa dalam proses belajar haruslah terjadi aktivitas secara akademis, aktivitas sosial, dan aktivitas moral dan spiritual yang terintegrasi (Sukadi, 2010).

Pada pembelajaran PKn konvensional, fase belajar yang di awali dengan doa cenderung diabaikan.
Belajar PKn yang di awali dengan aktifitas berdoa bersama bukan hanya sekedar mengajarkan anak untuk belajar berpikir irasional. Belajar dengan di awali dengan doa justru dimaksudkan dan dihayati serta dirasakan oleh siswa dapat memberikan energi dan keyakinan serta motivasi spiritual kepada peserta didik sebagai mahkhluk religius. Pikiran yang bersih dan keyakinan yang positif ini memberi implikasi untuk fokus pada kegiatan pembelajaran. Fokus pada kegiatan pemebelajaran tentu dapat menghasilkan out put belajar yang lebih baik. Disamping itu, siswa juga dapat menghayati bahwa kegiatan belajar adalah kewajiban berlandaskan dharma kewajiban suci dan bertanggujawab secara moral kepada Tuhan Yang Maha Esa (Subagia dan Wiratma, 2008).

Hal inilah yang dijelaskan oleh Sukadi (2010) sebagai aktifitas belajar yang dilandasi oleh yadnya bahwa kegiatan belajar dan mengajar itu adalah aktifitas yang suci dan untuk tujuan yang suci sesuai dengan adagiumnya Einstein yang menyatakan "science without religion is lame, religion without science is blind". Aktivitas belajar yang seperti ini pula yang membedakan pendekatan belajar Catur Asrama melalui Tri Kaya Parisudha dengan aktivitas belajar konstruktivisme ala Piaget dan Vygotsky (Suparno, 1996; Sukadi, 2010). Aktifitas belajar yang di awali dengan doa inilah yang dapat memberi awal yang baik sebagai usaha mewujudakan tujuan PKn untuk membentuk warga negara yang baik dan cerdas (smart and good citizenship); beriman, bermutu, dan berbudaya; humanis, holistik dan religius yang terintegrasi ke dalam kompetensi kewarganegaraan yang utuh.

Tahap belajar berikutnya adalah tahap inti pembelajatran, perbedaan utama fase belajar Catur Asrama 
melalaui taxonomi Tri Kaya Parisudha dengan pembelajaran secara konvensional, bahwa tujuan pembelajaran ini sedapat mungkin mampu mengantarkan siswa menghasilkan produk-produk belajar yang dapat di-yadnya-kan atau diibadahkan oleh siswa. Jadi, pembelajaran harus berbasis produk belajar yang hasilnya terdokumentasikan yang memenuhi kreteria; (1) mengandung pikiran atau ide-ide, gagasan yang baik dan benar (Manacika Parisudha); (2) dipresentasikan dengan baik dan benar, dengan pilihan kata-kata yang baik dan benar, tidak bohong, tidak sombong, tidak memfitnah (Wacika Parisudha); (3) serta menunjukkan tingkah laku atau tindakan yang baik dan benar (Kayika Parisudha).

\section{a. Fase Eksplorasi Melalui Fase Belajar Brahmacari}

Fase belajar ini diutamakan sebagai fase ekslorasi yakni fase belajar mandiri secara individu. Ada tiga kegiatan belajar utama yang dilakukan pada fase ini, yaitu memberikan tugas kokurikuler kepada siswa secara individu untuk dikerjakan secara mandiri di rumah, mendiskusikan hasil tugas kokurikuler di kelas, dan memeberikan konfirmasi oleh guru. Pemberian tugas korikuler dimaksudkan untuk mengeksplorasi pengetahuan awal dan pengalaman yang telah dimiliki oleh siswa. Di samping itu, siswa diarahkan untuk memiliki pengetahuan dan konsep dasar dan nilai-nilai esensial serta sikap dan kemandirian yang menjadi prasyarat yang diperlukan untuk dapat mengikuti kegiatan pembelajaran fase berikutnya. Hasil belajar kegiatan pertama ini dikaji lebih lanjut dalam diskusi di kelas. Diskusi di kelas memungkinkan siswa melakukan sharing informasi, pengalaman, pengetahuan, nilai-nilai, sikap, apresiasi dan penilaian. Di sini siswa belajar membandingkan, mengelompokkan, memadukan, dan menilai. Tujuan utama kegiatan diskusi tahap ini adalah menguji apakah pekerjaan yang menggambarkan pengetahuan awal dan pengalaman awal siswa secara individu mengandung miskonsepsi atau tidak. Ada tidaknya miskonsepsi ini dikonfirmasi oleh guru. Proses pembelajaran seperti ini relevan dengan proses pendekatan konstutivisme yang memanfaatkan pengalaman awal dan pengetahuan awal sebagai loncatan pertama dalam pembelajaran dan menghindarkan adanya miskonsepsi siswa (Suparno, 1997; Sukadi 2010: 144).

\section{b. Fase Elaborasi Melalui Fase Belajar Grehastha}

Fase inti pembelajaran kedua Catur Asrama adalah fase belajar grehastha. Fokus kegiatan belajar siswa pada fase ini adalah belajar berkelompok dan bekerja sama secara kooperatif seperti membentuk sebuah keluarga atau kelompok masyarakat. Secara simbolik fase belajar ini melambangkan kesiapan setiap individu untuk membentuk kesatuan keluarga yang menjadi unsur terkecil terbentuknya kelompokkelompok masyarakat (Sukadi, 2010).

Di sini siswa dilibatkan dalam belajar berdiskusi menggunakan model diskusi debat pro dan kontra, diskusi secara kooperatif menggunakan kelompok ahli, belajar melakukan investigasi kelompok. Diskusi kelompok pada fase ini tidak hanya mendiskusikan materi konsep-konsep esensial yang bersifat kognitif saja. Siswa juga belajar mendiskusikan kasus, masalah, nilainilai, sikap, keyakinan, komitmen, rasa percaya diri, dan keterampilanketerampilan sosial kewarganegaraan yang dibutuhkan. Begitu juga, diskusi tidak hanya berfokus pada pengetahuan intelektual saja, melainkan juga 
pengetahuan sosial, emosional, moral, dan pengetahuan spiritual siswa (Sukadi, 2010: 146)

Pentingnya fase belajar brahmacari ini karena di dalam pembelajaran PKn bukan hanya mengembangkan kecerdasan intelektual secara individu semata. Kecerdasan intelektual perlu disadari pula memiliki kelemahan karena pengaruh ikatan ego manusia. Faktor inilah yang sering menyebabkan manusia itu mau benar sendiri, mau menang sendiri, sombong atau congkak, dan takabur. Kecerdasan intelektual karena itu haruslah diasah untuk berinteraksi dengan kecerdasan intelektual orang lain. Ini tidak saja akan menimbulkan kebenaran interpersonal dan sosial yang akan membantunya mendekatkan diri kepada kebenaran objektif, tetapi juga memberikannya kepekaan sosial yang akan menjauhkannya dari kegelapan egoisme yang picik

Hal inilah yang dikritik oleh kontruktivisme De Vries dan San (dalam Sukadi, 2010) bahwa dalam proses belajar haruslah terjadi aktivitas akademis, aktivitas soaial, dan aktivitas moral dan spiritual; dan Fridjof Capra (2007: 17) menyatakan bahwa aktivitas belajar seperti ini sebetulnya merupakan pendekatan belajar konstruktivisme yang holistik, integratif, dan ekologis; bahwa realitas itu didasarkan pada kesadaran pada akan saling hubungan dan saling ketergantungan yang esensial pada aspek fisik, biologis, psikulogis, sosial, dan kultural serta spiritualnya.

\section{c. Fase Konfirmasi Melalui Fase} Belajar Wanaprastha

Fase inti pembelajaran yang ketiga adalah fase belajar wanaprasta yang dikaikan sebagai fase konfirmasi dalam pembelajaran. Fokus kegiatan belajar siswa pada fase ini adalah melakukan refleksi diri tentang apa yang telah dicapai dalam kehidupan membentuk keluarga dan masyarakat dalam belajar berkelompok dan bekerja sama secara kooperatif. Kegiatan refleksi juga diarahkan untuk menimbang apa yang unggul dan yang masih lemah, sehingga diperlukan perbaikan dalam belajar berkelompok tadi.

Tahap belajar berikutnya yang tak kalah penting pada pendekatan belajar Catur Asrama adalah melakukan pengamalan ibadah atau beryadnya melalui fase belajar Biksuka. Fase belajar ini cenderung tidak pernah terjadi dalam pendekatan konvensional. Fase belajar ini siswa masih berkelompok, belajar mensimulasikan bagaimana mengibadahkan "meyadnyakan" pengetahuan suci yang telah diperolehnya untuk disebarluaskan kepada seluruh masyarakat. Fokus hasil belajar yang dicapai untuk disosialisasikan ini merupakan keberhasilan siswa dalam berpartisipasi memecahkan masalah sosial yang dihadapi oleh warga negara dalam kehidupan sehari-hari dan optimalisasi kompetensi kewarganegaraan yang diwujudkan dalam keterampilan kewarganegaraan (Soemantri, 2001; Wahab, 2001; Winataputra, 2001, Maftuh dan Sapriya, 2005).

Ada beberapa unjuk kerja keterampilan sosial kewarganegaraan yang dihasilkan pada fase belajar bhiksuka ini, antara lain; (1) Kemampuan dalam mengidentifikasi, merancang, membuat dan mengajukan usulan pemecahan masalah, usulan kebijakan publik, membuat porto polio atau project citizen; (2) Kemampuan mempresentasikan (wacika parisudha) hasil belajar secara komunikatif dan berpengaruh; (3) Kemampuan membuat kemasan hasil belajar agar lebih menarik; (4) Serta kesungguhan anak dalam menyiapkan dan menampilakn 
unjuk kerja yang terbaik untuk di ibadahkan.

Prinsip utama fase belajar ini adalah bagaimana setiap individu atau kelompok siswa dengan semangat dan motivasi serta tujuan yang suci bisa memberikan yang terbaik bagi kelompok masyarakat, bangsa dan negara seperti yang nyatakan oleh John F. Kenedy atau seperti apa yg diajarkan oleh Mahatma Gandhi yang pada prinsipnya "jangan pernah bertanya apa yang bisa diberikan oleh masyarakat dan negara kepadamu, tetapi berbuatlah terbaik yang bisa kamu sumbangkan pada masyarakat dan negaramu (Sukadi, 2010).

Fase berikutnya adalah menyimpulkan hasil belajar. Siswa dan guru membuat simpulan hasil belajar untuk menjawab apakah tujuan pembelajaran yang ditetapkan telah tercapai atau belum. Pada kegiatan ini guru meminta siswalah yang pertama membuat simpulan hasil belajar. Guru membantu memformulasikan apa yang belum dapat disimpulkan oleh siswa sambil memberikan kritik dan saran. Kemudian setelah itu keguatan pembelajaran ditutup dengan melakukan doa bersama "bersyukur" dengan memanjatkan puji sryukur kehadapan Tuhan Yang MAha Esa.

\section{Kesimpulan}

Hasil penelitian ini secara umum dapat disimpulkan bahwa "ada pengaruh yang signifikan pada peningkatan kompetensi kewarganegaraan siswa dalam hal pengetahuan kewarganegaraan (civic knowledge), sikap kewarganegaraan (civic disposition), sikap kewarganegaraan (civic skill) dengan menggunakan pendekatan belajar Catur Asrama melalui taksonomi Tri Kaya Parisudha dibandingkan dengan pendekatan belajar konvesional". Peningkatan kompetensi kewarganegaraan siswa ini merupakan hasil dari penerapan 3 tahapan pembelajaran "pendekatan belajar Catur Asrama melalui taksonomi Tri Kaya Parisudha" dengan 10 langkah pembelajaran.

Dengan temuan penelitian di atas maka dapat direkomendasikan bahwa pendekatan belajar PKn dengan pendekatan belajar Catur Asrama melalui taksonomi Tri Kaya Parisudha dapat dipergunakan untuk meningkatkan kompetensi kearganegaraan siswa dan juga sebagai cara untuk mempertahankan kearifan lokal masyarakat Bali dalam bidang pendidikan dan pembelajaran dalam rangka mewujudkan warga negaranya mampu "berpikir glogal, bertindak lokal, dan komit terhadap bangsa dan negaranya (think globally, act locally, and commit nationally)".

\section{Daftar Pustaka}

Giroux. H. A. (1981). Ideology, Culture, and the Process of Schooling. Philadelphia: Temple University Press.

Jammer, Max. 1999. Einstein and Religion: Physics and Theology. Uneted Kingdom: Princeton University Press. (buku online: http://www.amazon.com).

Kaelan, H. (2003). Pendidikan Pancasila. Yogyakarta; Paradigma.

Murdiono, Mukhamad (2010). Strategi Pembelajaran Kewarganegaraan Berbasis Kearifan Lokal (Prosiding Seminar Nasional Lembaga Penelitian UNY). Lemlit UNY: Yogyakarta

Pai, Young. (1990). Cultural Foundations of Education. New York: Macmillan Publishing Company. 
Redja Mudyahardjo (2001). Pengantar pendidikan (sebuah studi awal tentang dasar-dasar pendidikan pada umumnya dan pendidikan di Indonesia). Raja Grafindo Persada: Jakarta

Sapriya. (2001). Analisis Signifikasi "Content" PKn Persekolahan dalam Menghadapi Tuntutan Era Demokrasi dan Penegakan Hak Asasi Manusia. Jurnal Civicus (1) 57-72. Bandung. Jurusan PMPKN. UPI.

Sapriya \& Maftuh Bunyamin (2005).Jurnal Civicus Pembelajaran PKn melalui Pemetaan Konsep. Bandung.Jurusan PKn. FPIPS. UPI.

Somantri, M. N. (2001). Menggagas Pembaharuan Pendidikan IPS. Bandung: PT Remaja Posdakarya.

Ayatrohaedi. (1986). Kepribadian Budaya Bangsa (Local Genius). Jakarta: Dunia Pustaka Jaya.

Sartini, Menggali Kearifan Lokal Nusantara, Sebuah Kajian Filsafati, Jurnal Filsafat, Agustus 2004, Jilid 37 No. 2, Universitas Gajahmada, Yogyakarta.

Subagia, I W dan I Gusti L. Wiratma (2008) Penerapan Model Siklus Belajar Berbasis Tri Premana Pada Pembelajaran Sains Di Sekolah. Jurnal Pendidikan dan Pengajaran. Singaraja: Universitas Pendidikan Ganesha.

Sugiyono. (2010). Metodelogi Penelitian Kuantitatif, Kualitatif dan $R \& D$. Bandung: Alfabeta.

Sukadi. (2010). Rekonstruksi Pemikiran Belajar dan Pembelajaran PKN SD Sebagai Yadnya dalam Rangka Perwujudan Dharma Agama dan Dharma Negara Berbasis Konstruktivisme. Laporan Penelitian Hibah Bersaing Tahap
II. Singaraja: Universitas Pendidikan Ganesha.

Suparno, R. Paul (1997). Filsafat Konstruktivisme dalam Pendidikan. Yogyakarta: Percetakan Kanisius.

Wahab, A Azis. (2001). Rekonstruksi Kurikulum PMPKN. Jurnal Civicus (1). Bandung. Jurusan PMPKN. UPI.

Wahab, A Azis \& Sapriya. (2011). Teori dan Landasan Pendidikan Kewarganegaraa. $\quad$ Bandung; Alpadeta.

Winataputra, U.S. (2001). Jati diri Pendidikan Kewarganegaraan sebagai Wahana Sistemik Pendidikan Demokrasi (Suatu Kajian Konseptual dalam Konteks Pendidikan IPS). Disertasi. Bandung: Universitas Pendidikan Indonesia. 